\title{
The Beauty of the Power: Muqarnas, Sharing Art and Culture across the Mediterranean
}

\author{
Alicia Carrillo-Calderero \\ Professor \\ Department of History of Art, Archaeology, and Music \\ University of Cordoba, Spain
}

\begin{abstract}
This paper aims to highlight the artistic exchanges between Sharq al-Andalus and elsewhere in the Mediterranean such as Ifriqiya and Norman Sicily, through the analysis of the pictorial decoration used in the cells of muqarnas preserved in the Dār al-Sughrā in Murcia and on the ceiling of the central nave of the Cappella Palatina in Palermo, works dating from the sixth/twelfth century. The paper defends the propagandistic nature of this decoration, because it uses motifs from the Abbasid painting of Samarra, dated in the third/ ninth century, inspired in turn by Sasanian motifs. The adoption of these motifs and the interest in recreating the spaces of the great Abbasid caliphs and even of the Sasanian kings embodies an act of official inauguration and of the acceptance of a Caliphal dignity lost by the Abbasid caliphs themselves, and recovered by these rulers of the sixth/twelfth century.
\end{abstract}

Keywords: Muqarnas, Sharq al-Andalus, Cappella Palatina, Abbasid painting, Sasanians.

Words: 10.183 including List of tables and figures.

\section{INTRODUCTION}

Among the various motifs that Islamic art used to decorate buildings, muqarnas decoration (a system of projecting niches used for zones of transition and for architectural decoration) is most notable. It came to play a major role in architectural decoration due to its strong aesthetic appeal and flexibility, readily adaptable to various surfaces. This intricate three-dimensional decorative scheme was a device forged and developed in Islamic contexts and thereafter employed in non-Muslim settings, as for example in the Cappella Palatina in Palermo (Sicily), built around 1132 by the Norman Emperor Roger II (r. 1130-1154).

What follows is a study of the artistic exchanges between Sharq al-Andalus and elsewhere in the Mediterranean such as Ifrīqiya and Norman Sicily, through the study of the pictorial decoration used in the cells of muqarnas preserved in the Dār al-Ṣughrā in Murcia and on the ceiling of the central nave of the Cappella Palatina in Palermo, both works dating from the sixth/twelfth century. Through this study, I seek to return to the subject of the network of influences between al-Andalus, Ifrīqiya, Egypt and Norman Sicily that Delgado Valero raised in an interesting article published in 1996 in the journal al-Qantara. ${ }^{1}$ This paper aims to continue this thoroughly well-documented study by way of another element, the pictorial decoration of the muqarnas cells of Murcia and Palermo: a subject noted in previous publications, but waiting for a work like this to deal with it in appropriate depth. ${ }^{2}$ Likewise, it should be noted that this issue has already been raised by different authors such as Navarro Palazón and Jiménez Castillo, as well as by Professor Momplet Míguez and, more recently, by Dahmani ${ }^{3}$. However, to understand this artistic parallel, it is necessary to establish and put into

\footnotetext{
1“"El arte de Ifrīqiya y sus relaciones con distintos ámbitos del mediterráneo: al-Andalus, Egipto y Sicilia”, alQantara 17, 1996, 291-311.

2 Carrillo, "Compendio de los Muqarnas: Génesis y Evolución (siglos XI-XV)” and Carrillo, “Architectural Exchanges", 80, nota 17.

${ }^{3}$ Navarro Palazón, "La Dār al-Ṣugrā”, 119; Momplet Míguez, El arte hispanomusulmán, 116 and Dahmani, "Remarques", 163-176.
} 
context the framework of influences between the two regions, an issue hardly considered by these publications; this is what is proposed in this paper.

But this work is not just an analytical study of such manifestations: it seeks to show the use of pictorial symbols directed towards the exaltation of the dignity of the ruler. As will be seen in the following lines, the use in the sixth/twelfth century of motifs and pictorial types from the Abbasid painting of Samarra of the third/ninth century (in turn inspired by Sassanian motifs) should be understood as the confirmation by the rulers of the sixth/twelfth century of the caliphal dignity that the great Abbasid caliphs once possessed.

\subsection{About Muqarnas Decoration in Al-Andalus and Sicily}

To embark upon a historical study on the use of muqarnas in architectural decoration is a complex task, since it is not easy to pinpoint the etymology of the term, nor the place and time at which muqarnas were first used ${ }^{4}$. In general terms, it can be said that muqarnas decoration arose for the first time in the East between the second/eighth and fourth/tenth centuries ${ }^{5}$ and spread from there to other parts of Dār al-Islām. The functional origin of muqarnas decoration goes back to the corner tripartite squinch $^{6}$ and was to give rise to a highly aesthetic formal structure, and indeed to a whole system of three-dimensional decoration. ${ }^{7}$

In the case of Al-Andalus, earlier art historians such as Torres Balbás considered that the Almohads (524-668/1130-1269) introduced muqarnas decoration into the Iberian Peninsula. ${ }^{8}$ He based this idea on the oldest surviving Andalusi muqarnas dome, known and dated to around the second half of the sixth/twelfth century, found in Seville Cathedral, the former Almohad al-Jāmi a mosque (567577/1172-1182). However, it is now known, thanks to the Andalusi geographer al-'Udhrī (393478/1003-1085), that the term muqarnas was mentioned in documents related to the Tá 'ifa of Almeria as early as the second half of the fifth/eleventh century. ${ }^{9}$ A historiographical contextualization of al'Udhrî's information leads to the very plausible conclusion that Almeria could have imported the idea of muqarnas from North Africa, since commercial contacts between their ports are thoroughly documented. ${ }^{10}$ Nor, of course, should one fail to take into account the possible exchanges between alAndalus and Egypt during this period, according to Torres Balbás and Arié, ${ }^{11}$ which took place

\footnotetext{
${ }^{4}$ The etymology of the Arabic term muqarnas has not yet been established. Several scholars agree that it comes from the Greek word $\chi o \rho \omega v i \varsigma$ (Latin coronis), meaning "cornice", according to Behrens-Abouseif, "Mukarnas", 501; also, on this subject see: Heinrichs, "The Etymology of Muqarnas", 175-184. Likewise, as for the place and time at which the muqarnas were first used: on the one hand, very few publications have focused on this topic, and on the other hand, archaeological remains are scarce. On this, see: De Beyliè, La Kalaa des BeniHammad, Creswell, The Muslim Architecture of Egypt, Grabar The Formation of Islamic Art, Tabbaa, "The Muqarnas Dome: its Origin and Meaning", Ettinghausen and Grabar The Art And Architecture of Islam 6501250 and Bloom, "The Introduction of the Muqarnas into Egypt", among other publications.

${ }^{5}$ Carrillo, "La influencia del arte sasánida", 111.

${ }^{6}$ The fragmentation of the squinch through the introduction of small concave niches in the form of pointed or keel arches.

${ }^{7}$ Ecochard, Filiation, 65 .

${ }^{8}$ Torres Balbás, Arte almohade, 19.

${ }^{9}$ Bosch Vilá, “¿Mocárabes en el arte de la taifa de Almería?”, 139-160; Carrillo, “Architectural Exchanges”, 6882. In fact, the information on muqarnas provided by al- 'Udhrī is supported by another written testimony, namely the Qalā'id al- 'aqyān by Ibn Khāqān (480-528/1087-1133). This text mentions the existence of a palace with muqarnas which was located outside the Gate of the Jews in Cordoba. In Dokmak's opinion, Ibn Khāqān must have written this text before the year 512/1118, and the place described must have been built during the second half of the fifth/eleventh century: see Dokmak, "Estudio de los elementos islámicos" (unpublished). However, up to now neither remains nor documentary sources have been found to confirm this hypothesis.

${ }^{10}$ Sālim, “De al-Andalus a Egipto”, 141. Indeed, Bosch Vilá (1977, 152-153) mentioned - albeit in passing that the introduction of muqarnas into Almeria might have been due to the presence of artists coming from Qal 'at Ban̄̄ Hammād, Bosch Vilá, “¿Mocárabes en el arte de la taifa de Almería?”, 152-153.

${ }^{11}$ Torres Balbás, "Intercambios artísticos", 411-424; Arié, "Viajeros de Occidente a Oriente", 185.
} 
mainly through Almeria ${ }^{12}$ and which have been explained by the mediation of North Africa as a connecting route. ${ }^{13}$

In this respect, it is very probable that after the introduction of the muqarnas in the Tá 'ifa of Almeria in the fifth/eleventh century this decorative device could have been used in other parts of al-Andalus. Until now the oldest fragments of muqarnas found to confirm this hypothesis are part of a palace built during the rule of Ibn Mardanīsh (r. 542-567/1147-1172), the 'Wolf King' of the Christian chronicles and the man responsible for Murcia's significant role in the mid-sixth/twelfth century. ${ }^{14}$ There is a possibility that the use of muqarnas in Ibn Mardanīsh's Murcia forms part of a continuous artistic thread, perhaps inherited from the fifth/eleventh century Ța 'ifa of Almeria; another possibility is that the use of muqarnas in the Mardanishī period may have been a continuation of the artistic conventions used by the Almoravids (448/1056-541/1147). From that time onwards the technique continued to be used systematically in Andalusi art, with particular intensity in Nasrid art (seventh/thirteenth to ninth/fifteenth century), an example of which can be seen in the dome of the Sala de las Dos Hermanas in the Alhambra in Granada, dated to the eighth/fourteenth century.

It is important to emphasize the importance of muqarnas decoration for studies of Andalusi art. It also became part of the ornamental language of Mudejar art from the seventh/thirteenth century onwards. However, this use of muqarnas in examples produced by Christian art exists not only in the Iberian Peninsula (Spain and Portugal) but also in Sicily. In twelfth-century Norman Sicily the Islamic tradition prior to the Christian conquest had a very considerable influence, as can be deduced by the use of elements of Islamic art in the construction and decoration of the main buildings. This use of Islamic elements in the Christian architecture of Sicily is known as Siculo-Norman art, and very interesting examples still survive.

The presence of this Islamic component in the artistic context of the island can be explained by the legacy that the Muslims left behind after two centuries of political domination. Indeed, from the early days of Islam Sicily was a clear objective in the flow of trade of the Mediterranean; the Muslims of the Maghreb therefore decided to make the island an allied territory. ${ }^{15}$ During the period of Muslim domination on the island commercial relations thrived, not only with Ifrieiya, Egypt and the southern Muslim ports ${ }^{16}$ but also with the coastal states of Italy such as Naples, Salerno and Amalfi. ${ }^{17}$ This intense traffic brought great wealth to the island, and at the same time makes clear the relations that existed among the different regions of the Mediterranean. ${ }^{18}$ The end of the Muslim domination of Sicily was precipitated from 431/1040 onwards, when the island was attacked by the Byzantines and by Italian city-states such as Pisa. This all led to a period of the disintegration of Arab rule in Sicily into a series of tawa' if, paving the way for the first appearance of the Normans in 1060 and the subsequent reincorporation of Sicily into Christendom. ${ }^{19}$ As for relations with the Maghreb in this period of Christian domination of the island, not only did they continue, but contacts became even closer. $^{20}$

12 Not to mention the Syrian merchants who maintained trading relations with al-Andalus by way of the North African coast, Sālim, "De al-Andalus a Egipto", 141.

13 On the subject of commercial relations between the Maghreb and Al-Andalus since ancient times, very interesting descriptions are given by Arab geographers, such as al-Bakrī writing in the fifth/eleventh century; alIdrīsī in the sixth/twelfth; al-Himyarī (mentioned above), in the eighth/fourteenth; and the Eastener Ibn Hawqal, who travelled through Al-Andalus and the Maghreb in the mid fourth/tenth century: see Lirola Delgado, El poder naval de al-Andalus, 121.

14 Molina López, "La kūra de Țudmīr", 28.

15 Sicily was conquered from the Byzantines at the beginning of the third/tenth century. After several years of Aghlabid and Fatimid rule, in the middle of the third/tenth century a new dynasty, the Kalbids (337/445948/1053), established a state, semi-independent of the Fatimids, see Ahmad, A History, 25; Bosworth, The new islamic dynasties, 33 .

16 Amari, Storia dei musulmani, vol 2, 448-450.

17 Molinari, "La Sicilia islámica", 44-45.

18 Contacts with the Maghreb and Al-Andalus, see Cilento and Vanoli, Arabi e Normandi, 62; but also very interesting trading relations between Muslims and Christians that also included the exchange of artistic objects, as shown by Hoffman in "Pathways of Portability", 17-50, Rosser-Owen, "Mediterraneanism", 1-33 and Mathews "Plunder of war or objects of trade?", 233-258.

19 Mallette, The Kingdom of Sicily, 5.

${ }^{20}$ Albulafia, Italy, Sicily, 27, 34-36. 
Among the Norman monarchs the figure of Roger II (r. 1130-1154) is fundamental, for he was the most famous of all. Under him several Muslims formed part of the Royal administration, such as Abūs-Salt Umayya and al-Idrīsis. ${ }^{21}$ This presence and persistence of the Islamic component in the government of Roger II was very important, not only because of the presence of Muslim intellectuals in the royal administration, but primarily because of the Norman monarch's respect for the Islamic heritage of the island and his wish to maintain $i^{22}$. Similarly, the control of the Mediterranean and the commercial contacts with the cities of North Africa and Egypt made it possible to increase the artistic influences in Sicily: It would thus be at this time that the most beautiful expressions of Siculo-Norman art were produced. This type of artistic expression became the hallmark of Norman Sicily, especially under Roger II, until the arrival of Frederick II of Hohenstaufen (r.1198-1250) to the throne, when there was a strong Europeanization of Sicilian culture. ${ }^{23}$

The use of muqarnas decoration in Siculo-Norman art is common, and there are therefore notable and very interesting examples such as the Cappella Palatina built in the period of Roger II (r. 1130-1154) and the Zisa Palace (1164) by William I (r. 1154-1166), ${ }^{24}$ in Palermo.

\section{Artistic Similarities Between Sharq Al-Andalus and Norman Sicily During The 6Th/12Th Century Seen Through the Study OF MuQuarnas DeCoration}

Indeed, contact between the different areas of the Mediterranean in the mid centuries of the Middle Ages (fifth/eleventh and seventh/thirteenth centuries) is a well proven fact; but it should be understood not only from the economic or commercial point of view but also from the cultural and artistic. In this regard, it is necessary to give a general historical tour of Andalusi art, in which can be seen the constant artistic influences to and from either side of the Strait of Gibraltar.

It is therefore important to point out that contacts between the Maghreb and Al-Andalus had already become common from the third/ninth century onwards, as can be seen in the use of a ribbed dome in the now lost mosque of Pechina, in Almeria, dated to the third/ninth century, as stated in the descriptions of Ahmad al- ${ }^{\circ} \mathrm{Udr} \mathbf{1}$ (393/1003-478/1085) and Ibn 'Abd al-Mun 'im al-Himyarī (b. 5th/11th c.- d. 900/1494). ${ }^{25}$ The presence of this ribbed dome is evidence of the Aghlabid influence in southern Al-Andalus, for the Great Mosque of Kairouan in Tunis (221/836) conserves the first example of this type of dome so far documented in the Maghreb. Despite the well-known difficulty of establishing the origin of domes using ribs, ${ }^{26}$ the use of ribbed domes at the same time in Ifriqqiya and in the south of Al-Andalus reveals the contacts between the two sides. In this respect, according to Torres Balbás, these constant relations between Kairouan and Al-Andalus were due to the intense trade maintained between the two territories, as well as to pilgrimages to Mecca and the travels of educated Muslims. ${ }^{27}$

During the fourth/tenth century the artistic influences continued: indeed it is worth noting the oriental influence, as seen in the motives of Abbasid origin, stemming from Samarra, used in the ceilings of the extension of the Mosque of Cordoba by the Caliph al-Hakam II (350-365 / 961-976) in the middle of the fourth/tenth century. ${ }^{28}$ The artistic influence continued in subsequent centuries, as shown by the use of muqarnas decoration in Al-Andalus from the fifth/eleventh century on. In this respect, as

\footnotetext{
${ }^{21}$ At the orders of Roger II, Al-Idrīsī (493/1100-560/1165) produced a great map of the world and its written description, written in about 548/1154 and entitled "The Book of Roger" (al-Kitāb al-Rujarī) and "A diversión for the man longing to travel to far-off places" (Nuzhat al-mushtāq fì ikhtirāq al-āfāq): see Metcalfe, Muslims and Christians, 101 .

${ }^{22}$ According to Ibn al-Athīr, Roger II always protected the Muslims of the island, although at the end he became intolerant. See Ahmad, A History, 58.

${ }^{23}$ Mallette, The Kingdom of Sicily, 5.

${ }^{24}$ Garofalo, “A Methodology for Studying Muqarnas”, 357.

${ }^{25}$ Pavón Maldonado, Tratado de arquitectura, 680 and 688.

${ }^{26}$ Gómez-Moreno, El arte árabe español, 115; Lézine, Architecture de L'Ifriqiya, 61; Pavón Maldonado, El arte hispanomusulmán, 156-157.

27 Torres Balbás, “Aportaciones del arte de Ifrīqiya”, 394 y 395.

${ }^{28}$ Hernández Jiménez, "La techumbre de la Gran Mezquita de Córdoba”, 191-225; Pavón Maldonado "Las analogías entre el arte califal de Córdoba", 36; Cabañero Subiza and Herrera Ontañón, "Nuevos datos para el estudio de la techumbre", 257-283. According to Torres Balbás, they must have reached Cordoba originating from Ifrīqiya; see Torres Balbás, "Aportaciones del arte de Ifrīqiya”, 395.
} 
mentioned above, it is now known thanks to the Andalusi geographer al- ${ }^{\circ}$ Udhrī (393-478/1003-1085) that the term muqarnas was mentioned in documents related to the Tiá'ifa of Almeria as early as the second half of the fifth/eleventh century. ${ }^{29}$ The presence of these elements in the south-east of alAndalus is explained by the commercial contacts that the Andalusian coast, and essentially Almeria, had regularly with the Maghreb and Egypt, as noted in numerous publications. ${ }^{30}$ It is very probable that after the introduction of the muqarnas in the Tá' 'ifa of Almeria in the fifth/eleventh century this decorative device could have been used in other parts of al-Andalus. In this sense, until now the oldest fragments of muqarnas found to confirm this hypothesis are part of a palace built during the rule of Ibn Mardanīsh (r. 542-567/1147-1172).

The examples of muqarnas found in Murcia formed part of the so-called Dār al-Sughrā (now known as the Old Palace of Santa Clara to distinguish it from the Qașr al-Sagì or New Palace of Santa Clara). ${ }^{31}$ The attribution to Ibn Mardanīsh of this palace, built in about 539/1145, ${ }^{32}$ and not in the preceding Almoravid period, is based on the analysis of the arabesques that decorate the plasterwork, with a style and technique different from that used previously in Andalusi art. ${ }^{33}$ The cells of muqarnas are made of brick, covered afterwards with stucco and then with paintings, which must have formed part of the decoration of a cupola of this palace. The painted images depict natural, geometric and figurative motifs. The examples showing plant decoration generally show the motifs on a red painted background, and are usually single and double palmettes as well as flowers and fruits. As Navarro Palazón has shown in his numerous publications on the subject, this painted plasterwork is closely related in style to the carved plaster belonging to the same palace. ${ }^{34}$ The geometric decoration generally consists of friezes made of strings of small beads decorating the edges of the muqarnas cells (Figure 1).

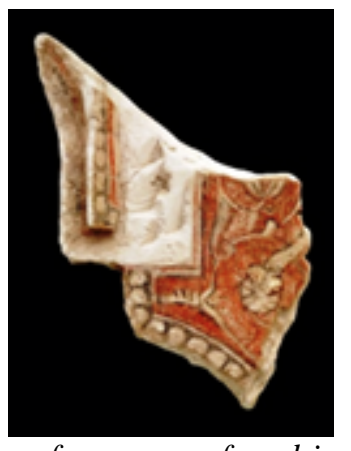

Figure1. Remainsof muqarnas found in the excavations of the Convent of Santa Clara, Murcia dated to the Mardanisī period (543/1148-567/1172) (MSCL/CE 070126, $304 \times 213 \mathrm{~mm}$. Archive of the Museum of Santa Clara, Murcia)

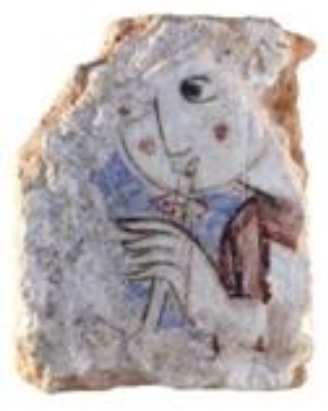

Figure2. Remains of muqarnas -flautist- found in the excavations of the Convent of Santa Clara, Murcia dated to the Mardanisi period (543/1148567/1172). (MSCL/CE 070179, 120 × $90 \mathrm{~mm}$. Archive of the Museum of Santa Clara, Murcia)

\footnotetext{
${ }^{29}$ Seco de Lucena, "Los palacios del taifa almeriense al-Mu tașim", 16-17. On this subject, see also: Ahmad al'Udhrī, Tarșī' al-akhbār wa-tanwī' al-āthār wa-l-bustān fì gharā'ib al-buldān wa-l-masālik ilà jamī' almamālik (The book of adornment of reports and classification of monuments and gardens, on the wonders of lands and the routes to all kingdoms), in Fragmentos geográfico-históricos de al-Masālik ilà ŷamī al-mamālik, edited by 'Abd al-Az̄̄z al-Ahwān̄i. Madrid: Instituto de Estudios Islámicos, 1965.

${ }^{30}$ Torres Balbás: "Intercambios artísticos entre Egipto y el Occidente musulmán" (1935) and "Aportaciones del arte de Ifrīqiya al musulmán español de los siglos X y XI" (1935); the article cited above by Delgado Valero, "El arte de Ifrīqiya"; Sālim, "De al-Andalus a Egipto y de Egipto a al-Andalus" (1995) and Azuar Ruiz, "AlAndalus y el comercio mediterráneo del siglo XI, según la dispersión y distribución de las producciones cerámicas" (1996), among other publications.

${ }^{31}$ According to Navarro Palazón, to whom owe the main studies done on the Mardanishi period, these are two names for the same post-Almohad palace, probably built by Muhammad b. Yūsuf Ibn Hūd (625/1228635/1238), and constructed on top of the remains of earlier Mardanishī buildings: Navarro Palazón, "La Dār alȘugrā de Murcia", 99.

${ }^{32}$ Navarro Palazón and Jiménez Castillo, "La arquitectura de Mardanīsh”, 328.

${ }^{33}$ Navarro Palazón, "La Dār al-Ṣugrā de Murcia”, 121.

${ }^{34}$ Navarro Palazón and Jiménez Castillo, “La arquitectura de Ibn Mardanīsh”, 307.
} 
However, the most interesting depiction is figurative. Particularly remarkable is the presence of a figure, apparently a woman because of the representation of rouge on her cheeks, which appears with a wind music instrument, the mizmar (Figure 2). This piece is on display in the Museum of Santa Clara in Murcia together with other very interesting remains of muqarnas, like the fragment that shows a seated bearded man (Figure 3), whose posture is hard to determine owing to the fragmentation of the piece and its deteriorated state. In the opinion of Navarro Palazón, it is possible that the figure is carrying on his shoulder a staff, or more likely the stem of a plant representing abundance in the form of a leaf or palmette. ${ }^{35}$ In either case they are attributes of power symbolizing the dignity of the Prince and the opulence and fertility that exist under his rule, though the figure carrying it should not be identified with the sovereign. ${ }^{36}$ A third image, also incomplete, represents the lower part of some legs, with bare feet and part of a reddish coloured tunic (Figure 4).

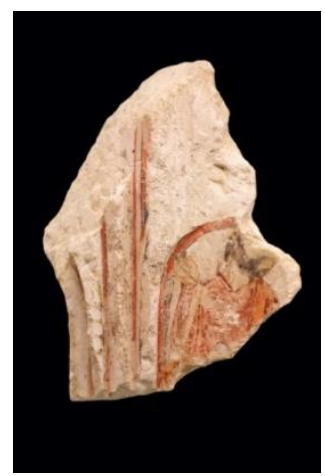

Figure3. Remains of muqarnas - bearded manfound in the excavations of the Convent of Santa Clara, Murcia dated to the Mardanisī period (543/1148-567/1172). (MSCL/CE 070128, $375 \times 315$ mm. Archive of the Museum of Santa Clara, Murcia)

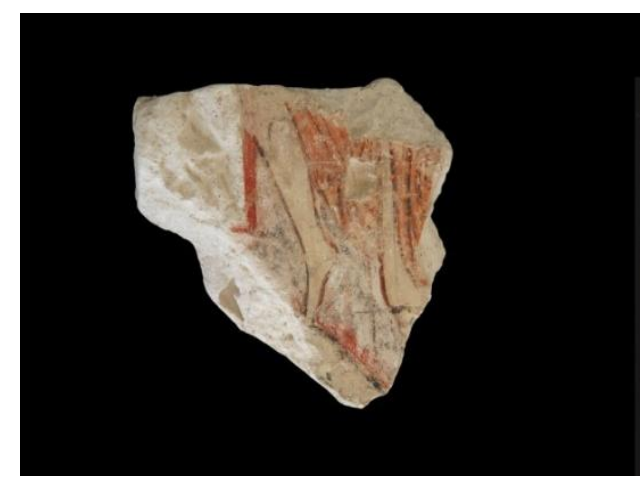

Figure4. Remains of muqarnas - feet- found in the excavations of the Convent of Santa Clara, Murcia dated to the Mardanisi period (543/1148-567/1172). (MSCL/CE 070181, $175 \times 188 \mathrm{~mm}$. Archive of the Museum of Santa Clara, Murcia)

This piece is displayed in the Santa Clara Museum separately from the fragment showing the bearded man; however, in my opinion they form part of the same scene, as shown in the photomontage in Figure 5. In this sense, despite the fragmented state of both pieces it is possible to continue the drawing and to suggest that it must have been the figure of a possible bearded "sovereign", seated (as seen from the position of his feet) and carrying a flowering rod or else a staff for directing a hunt. This is in line with representations of the same type such as that surviving in the left-hand nave of the great hall of Qusayr 'Amra from the second/eighth century (Figure 6). ${ }^{37}$ Another possibility is that it may be a musician, also seated, playing some sort of instrument with a long neck.

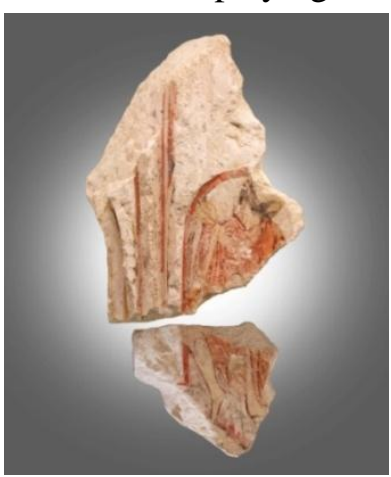

Figure5.Photographicmontage:remains of muqarnas found in the excavations of the Convent of Santa Clara, Murcia dated to the Mardanisī period (543/1148-567/1172).

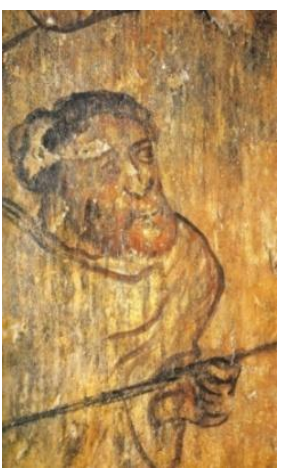

Figure6. Portrait of the caliph or prince leading the hunt in the left-hand nave of the great hall of Qusayr 'Amra. Almagro Basch, et al. (2002) Qusayr 'Amra. Residencia y baños omeyas en el desierto de Jordania. Granada: El Legado andalusí. 83.

\footnotetext{
${ }^{35}$ Navarro Palazón and Jiménez Castillo, "La arquitectura de Mardanīsh", 308.

${ }^{36}$ García García, "El soberano en al-Andalus", 61; this may be the sceptre-staff or qaḍīb, see Pérez Higuera, Objetos e imágenes, 55-58.

${ }^{37}$ About Qusayr 'Amra, see Almagro Basch, M. et al. Qusayr 'Amra, 83.
} 
Another fragment, also incomplete, depicts the top of a turbaned head represented with broad strokes of orange-red, and shows part of the right eyebrow, whose rounded shape is reminiscent of the style of Abbasid art (Figure 7). Other examples display body parts, such as a bust of what looks like a dancer, of which more later (Figure 8), and the head of a small bird, probably an eagle by the characteristics of its head and beak (Figure 9).

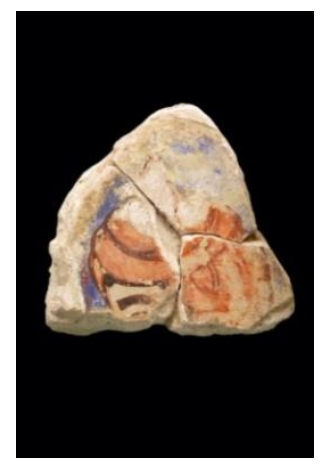

Figure7. Remains of muqarnas - turban-found in the excavations of the Convent of Santa Clara, Murcia dated to the Mardanisi period (543/1148567/1172). (MSCL/CE 070127, $197 \times 195 \mathrm{~mm}$. Archive of the Museum of Santa Clara, Murcia)

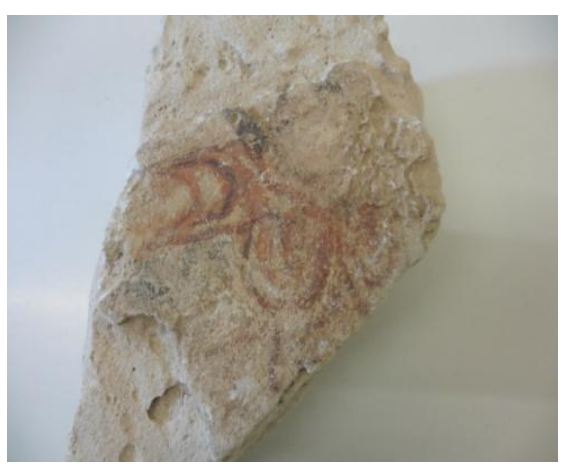

Figure8. Remains of muqarnas - dancer-found in the excavations of the Convent of Santa Clara, Murcia dated to the Mardanisi period (543/1148-567/1172). (SC853AVIII19, $277 \times 119 \mathrm{~mm}$. Archive of the Museum of Santa Clara, Murcia)

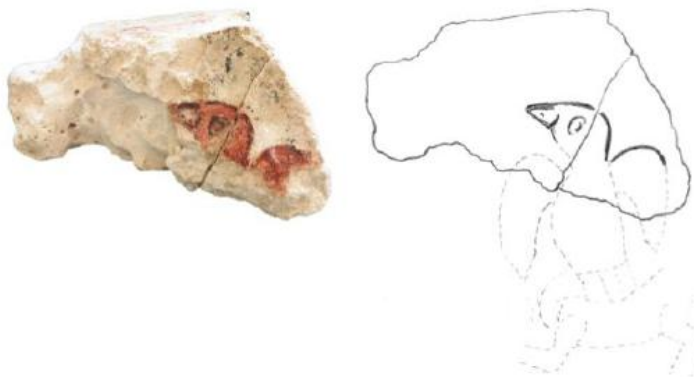

Figure9. Remains of muqarnas - eagle-found in the excavations of the Convent of Santa Clara, Murcia dated to the Mardanisi period (543/1148-567/1172) and author's sketch. (MSCL/CE 070130, $90 \times 140 \mathrm{~mm}$. Archive of the Museum of Santa Clara, Murcia)

As to the origins of these paintings, it is clear that two separate artists were at work, with different styles. It is very difficult to reconstruct the original aspect of the dome, for the surviving fragments are few and the paintings are not in a good state of preservation. Nevertheless, the features of the female figure playing the mizmar show a more lineal and more careful line than in the other pieces, where volume dominates line. Thus the remains of the eagle, dancer, turbaned head, and feet do not show the fine black line or the meticulousness of the figure with the mizmar, which demostrates the existence of more than one artist. Regarding the origin of the creators of these paintings, it is likely that in the decoration of his palace Ibn Mardanīsh employed craftsmen from Maghreb, because in al-Andalus there are no examples, either contemporary or previous, that show the same type of painting in the Abbasid tradition. In the Maghreb, on the other hand, there are examples of muqarnas of this type, as for example in the remains of muqarnas found in the Qașr al-Saläm (Palace of Peace) of the Qal'at of the Banī Hammād (397-534/1007-1152) in Algeria and dated in the fifth/eleventh century. However, if it is accepted that there were two different artists, it is probable that an initial craftsman, or group of artists, came from the Maghreb. These would be the ones who painted the figure playing the mizmar and probably other pieces with figurative decoration so far not known to have survive; and a second school, perhaps local, must have produced the rest of the fragments where volume dominates line

In any case, generally speaking the characteristics of these paintings from Murcia, such the kind of figurative representation (facial features, attitudes, postures and even the motifs depicted) are similar to those in the decoration of the muqarnas cells used in the Cappella Palatina in Palermo. This building was constructed on the orders of the Norman king Roger II (r. 1130-1154) between the years 
1132 and 1143. The Cappella Palatina, is undoubtedly at the same time one of the most representative and enigmatic buildings, due to the use of artistic elements of Islamic origin in a religious building, such as in the ceiling of the nave. ${ }^{38}$ It was clearly used as a place for royal receptions, designed to show majesty, power and divine authority. ${ }^{39}$ The interior space is organized into three aisles decorated with an extraordinary iconographic series, in which remarkable use is made of paintings and mosaics reproducing various motifs and religious scenes. However, what is most interesting for the purposes of this paper is the ceiling covering the nave, which uses muqarnas decoration to cover the entire surface, as well as star-shaped polygons which contribute to the creation of a celestial sphere, in accordance with the magnificence of the Norman king (Figure 10 and Figure 11). These stars are decorated with arabesques and inscriptions reading happiness, strength, peace and perfection, among other expressions. ${ }^{40}$ The muqarnas cells have a pictorial decoration showing plant and geometric motifs and fascinating figurative animal and anthropomorphic images.

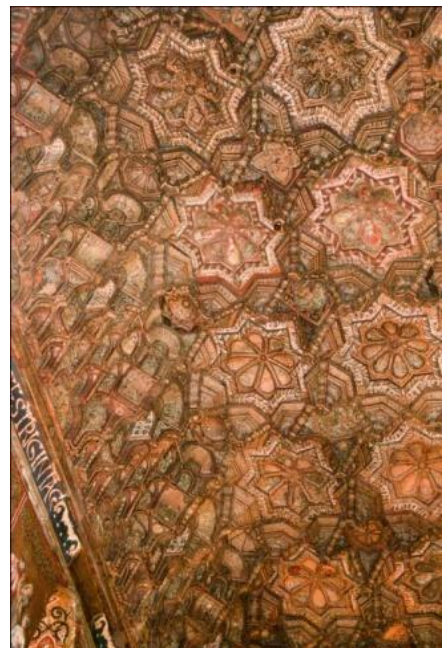

Figure10. View of the ceiling of the central nave of the Cappella Palatina in Palermo (1132-1143) (Author's Photograph, November 2013)

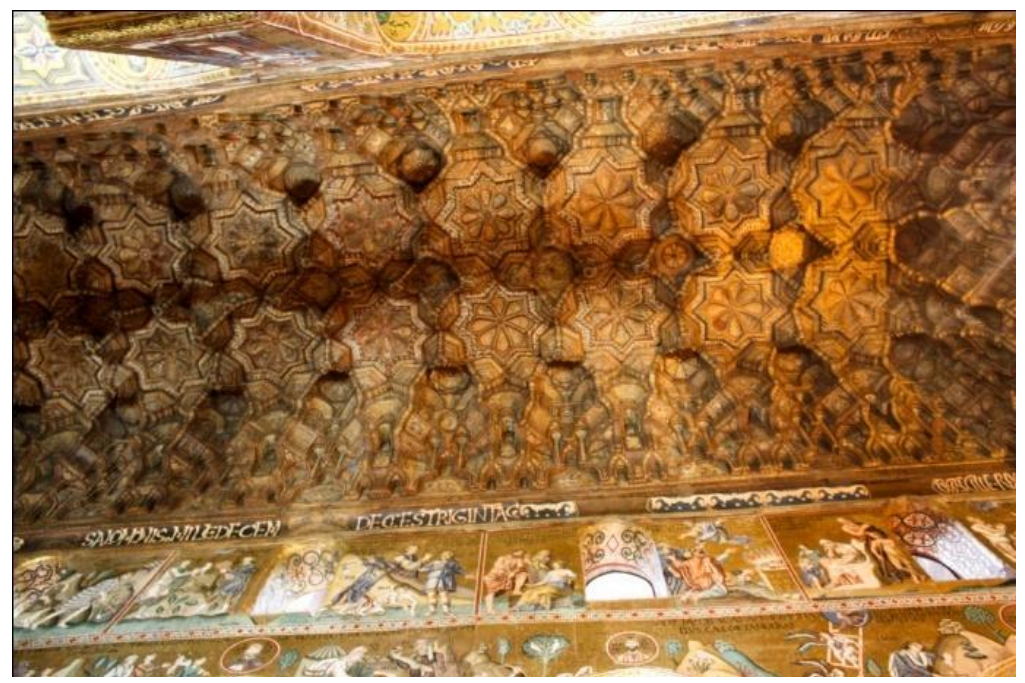

Figure11. View of the ceiling of the central nave of the Cappella Palatina in Palermo (1132 y 1143) (Author's Photograph, November 2013)

Much research has been done on the building in general and on this pictorial decoration in particular: that of Ugo Monneret de Villard, entitled precisely Le pitture musulmane al soffitto della Cappella Palatina in Palermo and published in 1950, is the first comprehensive investigation of the paintings

\footnotetext{
${ }^{38}$ Ćurčić, "Further thoughts on the palatine aspects", 526.

${ }^{39}$ Metcalfe, The Muslim of Medieval Italy, 237.

${ }^{40}$ Cruikshank Dodd, "Siculo-Arabic Ivories”, 159.
} 
of the wooden ceilings covering the nave. ${ }^{41}$ According to a study of the paintings, many of which have been lost and others of which have been restored several times, ${ }^{42}$ there are notable links with the pictorial tradition used by the Fatimids (297/909-567/1171) in Egypt, strongly influenced by Abbasid paintings in Samarra.

Notable among the figure paintings is the fact that most of the male figures wear a kind of turban or three-pointed crown, as seen for example in Figure 12. Similarly, musicians stand out, depicted with musical instruments common in the Islamic world, such as the lute or ' $\bar{u} d$, hunters, drinkers and also dancers. These pictures are related to the theme of the "princely cycle", since they represent the activities carried out in the banquets or feasts dedicated to the sovereign, which existed already in Sasanian art.

In Monneret de Villard's opinion there is no specific plan to the iconography, but the paintings are scattered arbitrarily according to the taste of the artist. Meanwhile, on the issue of authorship, Monneret suggests the possibility that there were several groups of artists, animal painters who had more in common with textile artists, and painters of human figures. ${ }^{43}$

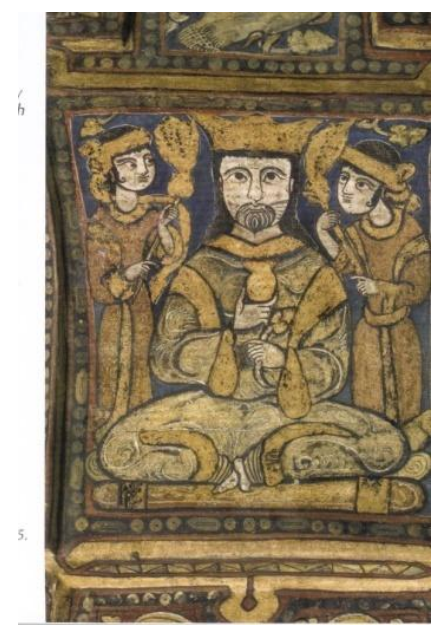

Figure12. Seated monarch: detail from the ceiling of the central nave of the Cappella Palatina in Palermo (1132 y 1143). La Cappella Palatina a Palermo/The Palatine Chapel in Palermo. Mirabilia Italiae Guide (2013) edited by Alessandro Vicenzi. Trento: Franco Cosimo Panini. 51.

In terms of its function, the Cappella Palatina today still presents many questions. The use of artistic elements from Islamic art, as well as expressions written in Arabic, in a religious building constructed by and for Christians has generated a very interesting debate on what Roger II's intention was, and on

\footnotetext{
${ }^{41}$ Prior to Monneret de Villard, there was a notable study done by Amari, Boglino, Cavallari and Carini: La Cappella di San Pietro nella Reggia di Palermo, dipinta e cromolitografata da Andrea Terzi, published in Palermo in1889, reprinted in Palermo, 1987. From then until now many studies have been published, like Nicole, "The Cappella palatina ceiling and the Muslim military" (1983), Tronzo, The Cultures of his Kingdom. Roger II and The Capella Palatina in Palermo (1997), Grube and Johns, The Painted Ceiling of the Cappella Palatina (2005), Agnello, "The Painted Ceiling of the Cappella Palatina in Palermo: an Essay on its Geometric and Constructive Features" (2010) and Hunt "Ceiling and Casket at the Cappella Palatina and Christian Arab Art between Sicily and Egypt in the Twelfth and Thirteenth Centuries" (2011), among other publications.

${ }^{42}$ According to an inscription, the ceiling of the central nave was restored in 1478 under King Giovanni, and completed in the reign of Ferdinand the Catholic, as well as a minor intervention in 1798. See Monneret de Villard, Le pitture musulmane, 21-22. The most recent restoration took place between the years 2005 and 2009: see Agnello, "The painted ceiling", 407.

${ }^{43}$ Concerning the provenance of these anonymous artists, there are various opinions, but at the time of writing there is no documentation to confirm the provenance of the group of painters or craftsman decorators who executed this ceiling. In the opinion of Monneret de Villard, the craftsmen must have come from Fatimid Egypt or they could even have come from Edessa or from the Diyār Bakr. Monneret de Villard, Le pitture musulmane, 55-56. For Erica Cruikshank, irrespective of their place of origin, Muslim and Christian artists must have been working together, in view of the mixture of motifs to be seen, the result of the confluence of the two cultures and their influence on each other, Cruikshank Dodd, "Siculo-Arabic Ivories", 153 and 166.
} 
the kind of message that he wanted to transmit and perpetuate in history. All the publications dedicated to this building have spoken about it: in general the decoration of the Cappella Palatina in Palermo has been interpreted as an adoption by the Norman monarch of symbols and courtly motifs related to the Islamic Paradise, dedicated to his royal person. ${ }^{44}$

At this point, it is clear that there is a technical similarity between the pictorial decoration of the muqarnas of the Dār al-Sughrā in Murcia and the Cappella Palatina in Palermo. Precisely, it is possible to identify the meaning of the decoration in Murcia by studying the ceiling of the Capella Palatina in Palermo. In both cases, it is the "princely cycle", recreating the activities taking place in the banquets or feasts dedicated to the king, with scenes of hunting, music, monarchs on their thrones, and sensuous dancing girls. Similarly, according to typological and iconographic analysis of these examples, a link to the Abbasid painting used in the third/ninth century in Samarra is clearly seen. Indeed, as shown by the different examples preserved in the Jawsaq al-Khaqānī palace, extensively researched by Herzfeld in his great study on this city founded by Abū Isḥāq al-Mu tașim (218/833$227 / 842$ ) in the year $221 / 836,{ }^{45}$ there are figures, postures and characteristic forms similar to the examples in Murcia and Palermo. Prominent on the walls of the Jawsaq al-Khaqāni palace is the use of small balls like beads to frame the motifs, generally of animals such as birds or ducks, forming small scrolls; these animals, for their part, are clearly of Sassanian inspiration as can be seen, for example, in the pieces of Sassanian silver held in various of the world's museums. ${ }^{46}$

In spite of the poor state of preservation of the Murcia fragments showing figure decoration, it is possible to draw very interesting parallels with the examples located in the Capella Palatina. A very interesting example is that of the female dancers or dancing figures, whose origin is again found in Abbasid painting of Samarra and in the Sasanian painting. ${ }^{47}$ Thus in the place occupied by the harem in the Jawsaq al-Khaqānī palace part of a fresco has been preserved and reconstructed by Hertzfeld. It represents two dancing girls carrying a sort of shawl in their arms (Figure 13) ${ }^{48}$.

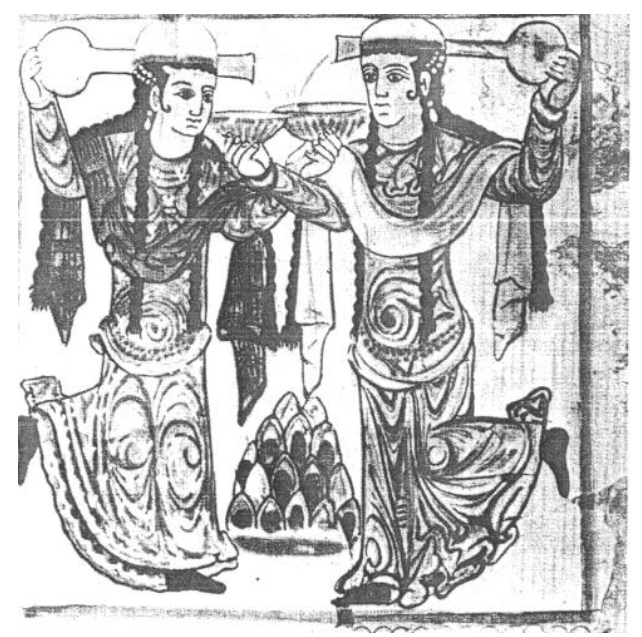

Figure13. Dancers. Mural painting from the Jawsaq al-Khaqān̄ palace in Samarra (third/ninth century) according to Hertzfeld's reconstruction of the original. Grube (1980). La pittura dell'Islam: miniature persiana dal XII al XVI sec. Bologna: Capitol. 10.

\footnotetext{
${ }^{44}$ Hunt, "Ceiling and Casket", 173.

${ }^{45}$ Herzfeld, Die Malereien von Samarra (Berlin, 1927).

${ }^{46}$ Rice, Islamic painting, 30 and 32. The Sasanian inspiration in Abbasid art can be explained by the move of the capital from Damascus to Baghdad. In the words of Eva Hoffman: “(...) The Abbasids had inherited local pre-Islamic Sasanian traditions in Iraq and Mesopotamia, the lands that served as the center of gravity for their empire, and they incorporated the visual traditions from the more eastern reaches of the empire as well", in Hoffman, "Between East and West", 109.

${ }^{47}$ It has been said that this Sassanian motif is derived from Dionisiac iconography and that it is connected with the fertility cult of the goddess Anâhitâ. See López Monteagudo, "Platería sasánida", 157.

${ }^{48}$ This is a Hellenistic model used in the earliest days of Christianity in Syria, Alexandria and Constantinople, although the long tresses of the hair and the belts decorated with jewels are oriental, and the facial types are of Persian origin. See Rice, Islamic painting, 33.
} 
This type of representation carries meaning and functionality consistent with the space in which it is located. The presence of such images in palace areas gives an air of festivity and, above all, of the exclusiveness of the space by and for the sovereign and his court.This was done by the Sasanian monarchs, as well as the great Abbasid caliphs, and Ibn Mardanīsh and Roger II. In Murcia part of the breast of a woman has survived, presumed to be a dancer, while in Palermo the example is very typical, being a female figure with sinuous undulating movements (Figure 14). The Murcia fragment conserves part of the bust and the arms, traced in thick strokes of reddish paint, as well as a patch of black paint on the shoulders which must have formed part of the hair. On the arms semi-circular brushstrokes emulate the folds of some sort of diaphonous garment, light for dancing. On the basis of the example in Palermo it is possible to continue the drawing of these arms in the Murcia fragment and thus to show that they must have been very similar pictures (Figure 15). It is very interesting to confirm the re-use of the Sasanian model by the Abbasids, and from them to other governors, including Christians such as Roger II. The use of dancers in Islamic art is linked, as we have said above, to the "princely cycle". Drinking, watching female dancers and hunting are all recreations belonging to this imperial cycle, which existed already in Sasanian art. These themes were developed further in the Umayyad, Abbasid, Fatimid and Persian periods to reflect not only the etiquette of formal occasions but more generally to indicate royal celebration of wealth, and cultural prosperity or political stability ${ }^{49}$. In this sense, as Baer has said: “(...) From the Sasanian tradition they inherited the frequent representations of royalty, royal entourages, and favorite royal pastimes. They also inherited from them the desire to demonstrate visually the continuity of their princely lineage by painting the "portraits" of their kings on the walls of their royal residences" $"$. There are similarities to the shape of these dancing-girls, for example, in Sicilian ivory objects attributed to Fatimid craftsmen and also dated to the fourth/eleventh century, such as the piece kept in the Bargello National Museum in Florence.

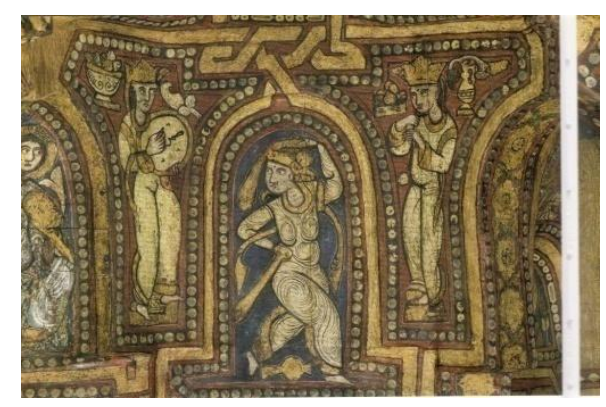

Figure14. Dancer: detail of the ceiling of the central nave of theCappella Palatina in Palermo (1132 y 1143). La Cappella Palatina a Palermo/The Palatine Chapel in Palermo. Mirabilia Italiae Guide (2013) edited by Alessandro Vicenzi. Trento: Franco Cosimo Panini. 48.

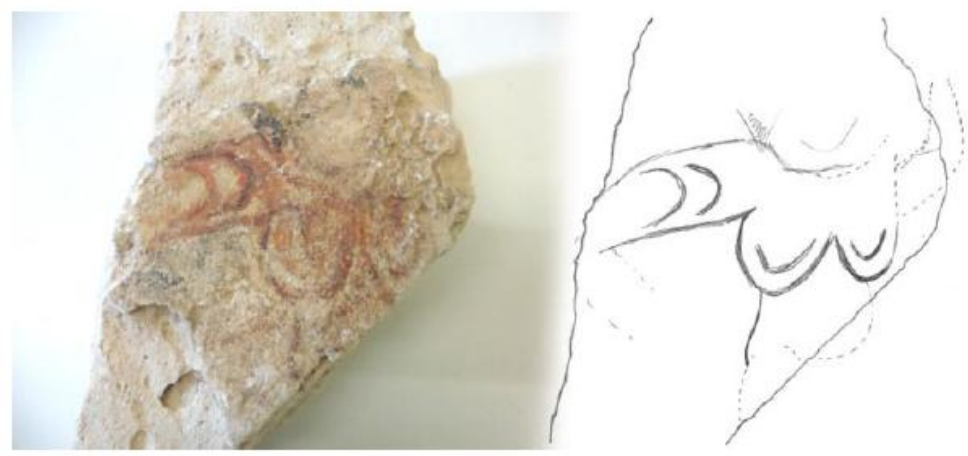

Figure15. Remains of muqarnas found in the excavations of the Convent of Santa Clara, Murcia dated to the Mardanisi period (543/1148-567/1172) and author's drawing. (SC853AVIII19, $277 \times 119 \mathrm{~mm}$. Archive of the Museum of Santa Clara, Murcia)

\footnotetext{
${ }^{49}$ Adly, "A Study on Islamic Human Figures", 7.

${ }^{50}$ Baer, "The Human Figure", 32.
} 
In light of the above, the similarity between the muqarnas decoration used in Palermo and a few years later in Murcia is not surprising. The relationships among the different areas of the Mediterranean are a manifest reality in these middle years of the sixth/twelfth century. Also at this time Murcia became a thriving city from the economic point of view, since it exported all kinds of manufactured goods to the Western Mediterranean. ${ }^{51}$ Norman Sicily for its part, especially with King Roger II at its head, remained in continuous contact with the cities of North Africa and Egypt, as mentioned above, and always in the interest of tight control of the Mediterranean. The existence of certain common architectural elements in Ifrīqiya, Al-Andalus, Egypt and Sicily should also be borne in mind, as Delgado Valero has shown. These elements are the memorial stone or burial column, the typical small square mosque divided into nine sections covered with a vault, and a structure characterized by a rectangular pond and pavilion in palace architecture. The existence of a pool linked to a rectangular pavilion in Murcia can be documented in the Castillejo of Monteagudo, from the fourth/twelfth century; and in Sicily the first documented example is the Favara, or Castle of Maredolce, attributed to the Kalbid governor Ŷa far ibn Yūsuf (388/998-409/1019). This building tradition would be used again on the island, for after the Norman conquest some palaces were built following this pattern, as was the case with the buildings linked with Roger II (r. 1130-1154) and his successors. ${ }^{52}$

To the question of how the influence of the Abbasid painting used in Samarra reached the Murcia of Ibn Mardanīsh, Ifrīqiya may be the answer. As already mentioned in this paper, the muqarnas of Murcia are the oldest preserved examples in al-Andalus, but it is known from the written reference of al-'Udhrī that in Almeria they were used in the palace of Abū Yahyā al-Mu'tașim (443/1051484/1091) in the fifth/eleventh century. It is unknown whether the muqarnas of Almeria were decorated with paintings of Abbasid style, like the preserved remains of the Qașr al-Salām (Palace of Peace) of the Qal' at of the Ban̄ Hammād (397/1007-534/1152) in Algeria and dating from the same period. What is not in doubt is that at the moment the pictorial decoration of the muqarnas cells of Murcia represented, a novelty in Andalusi art; it is therefore likely that its introduction in those middle years of the sixth/twelfth century was due to the contacts of Sharq al-Andalus with Ifrīqiya, as must have happened in Sicily.

Indeed, in Norman Sicily too it is possible to observe architectural reminders of the Maghreb, such as in the so-called Pisan tower of the Norman royal palace in Palermo, which had a prototype in the Qașr al-Manār (the Palace of the Beacon or Tower) of the Qal' at of the Ban̄ Hammād. ${ }^{53}$ Similarly, Jonathan Bloom said in 2005 that although the paintings in the Cappella Palatina can be linked to Fatimid Egypt, the structure of the vault cannot: it should probably be associated with the Qal ${ }^{\circ}$ at of the Banī Hammād, from where its builders came. ${ }^{54}$ Similarly, one cannot forget the influence of Egypt, although in this case it is not known whether it affected Norman Sicily directly or through Ifriqiya. In this case, it seems likely to have been a direct influence, first because of the existing Fatimid legacy on the island, and second because the Norman king is known to have good relations with the Fatimid Caliph. ${ }^{55}$

In this paper the role of Fatimid Egypt regarding this type of pictorial decoration is taken as fundamental. It is therefore worth noting that the Islamic Museum of Cairo now holds some muqarnas fragments- made of stucco and decorated with paintings - found in the Hammām of Abū'l-Su'ud, on the site of the old city of Fustạt; these remains feature a dancer and a young man sitting with a glass in his hand. It is believed that they were part of a cupola, perhaps as transitional elements. Some decades ago they were compared to Samarran Abbasid decoration, and accordingly dated to the third/ninth or

\footnotetext{
${ }^{51}$ Navarro Palazón and Jiménez Castillo, Sharq al-Andalus, no page numbers.

52 As to the origin, as Delgado Valero points out, the Abbasid tradition that used this system of pond and rectangular pavilion is clear, as can be seen for example in the palace of Jawsaq al-Khāqānī in Samarra built by Abū Ishāa al-Mu tașim (2187833 - 227/842), which must have inspired the North African examples. Ifrīqiya must have acted either as the focal point for the reception of this Abbasid tradition, or else the form of this structure was established there. See Delgado Valero, "El arte de Ifrīqiya", 309-310.

53 Johns, "I Re normanni", 22.

${ }^{54}$ Bloom, "Almoravid geometric designs", 74.

55 Johns, Arabic Administration, 258-259 and Albulafia, Italy, Sicily, 36: “(...) Roger had established quite cordial relations with the Fatimid caliph in Egypt, and it is likely that around 1150 ships under his protection could travel unmolested from Sicily via Tripoli to Egypt".
} 
fourth/tenth centuries. ${ }^{56}$ This chronology is not totally convincing. Instead, they may most probably be dated to the fifth/eleventh century onwards, ${ }^{57}$ which coincides with the extraordinary development undergone by muqarnas decoration in the Eastern Islamic lands. In these fragments, specifically in the one representing the seated man (Figure 16), the same features are seen as in the examples studied in this paper. So, for example and although there is no surviving similar figure in Murcia, the figure of a man and his seated posture with a glass in his right hand can be compared with several samples preserved in the ceiling of the Cappella Palatina in Palermo (Figure 12). And in fact in Fatimid Egypt there are further examples that show that link with Abbasid painting, such as can be seen in ceramic pieces dating from the same sixth/twelfth century ${ }^{58}$. In the same line, Hunt has shown that the paintings in the Cappella Palatina can also be compared to Egyptian Christian paintings, ${ }^{59}$ which enables us to confirm the direct influence of Egypt on Norman Sicily.

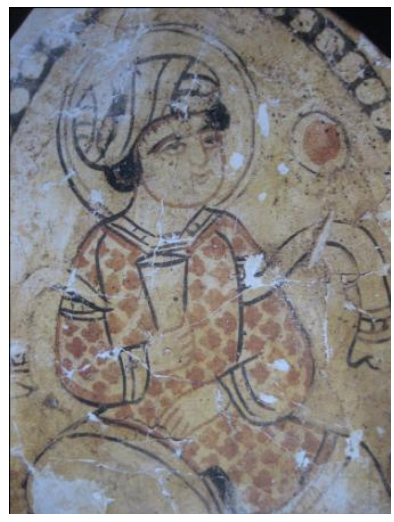

Figure16. A muqarnas fragment from the Hammām of Abū'l-Su'ud in Fustāt. André Raymond et al. (2000). Le Caire. Paris: Citadelles \& Mazenod. 132.

\section{CONCLUDing REMARKS}

At this point, it only remains to clarify some of the points discussed in this paper. So, as I stated at the beginning of my presentation, this article aims to continue the study Delgado Valero published in 1996 which revealed a network of influences between Al-Andalus, Ifrīqiya, Egypt and Norman Sicily through a series of artistic elements. In this paper I propose to add yet another element to those put forward by Delgado Valero: the pictorial decoration of the muqarnas cells of the Dār al-Șughrā in Murcia and of the ceiling of the central nave of the Cappella Palatina in Palermo. The fact is that exchanges and artistic influences between different regions of the Mediterranean are a reality that cannot be ignored in these middle centuries of the Middle Ages.

Indeed, as has been demonstrated throughout these lines, between 1130 and 1172 approximately the same type of painted decoration is documented in muqarnas cells used to decorate a possible dome in Murcia - Sharq Al-Andalus, and a ceiling in Palermo - Norma Sicily. I would here like to highlight the use of this Abbasid painting style as a symbol of the glorification of the ruler. Indeed, and although little is known about the exact function of this kind of pictorial decoration in the two examples, what is beyond doubt is its purpose for propaganda. In the case of Murcia, it is possible to glimpse a gesture of superiority by Ibn Mardanīsh, for he had managed to remain independent of the unstoppable Almohad pressure in Al-Andalus. Furthermore, according to the motifs represented in the muqarnas cells, it is clear that these paintings intend to recreate a courtly environment, fitting for a caliph, who also is described in Arab sources as Ibn al-Khatib, as recorded by Garcia Avilés. ${ }^{60}$

\footnotetext{
${ }^{56}$ Behrens-Abouseif, "Muḳarnas", 501.

${ }^{57}$ Carrillo Calderero, "La influencia del arte sasánida”, 102.

${ }^{58}$ Cruikshank Dodd, "Siculo-Arabic Ivories", 157 (illustrations).

${ }^{59}$ Hunt, "Ceiling and Casket at the Cappella Palatina", $175 \mathrm{ff}$.

60 García Avilés, “Arte y poder en Murcia”, 31: “(...) Tales banquetes eran animados por esclavas especializadas en la música, con sus flautas y sus laúdes. Con todo ello creaba un ambiente de extraordinaria diversión y así se adueñaba de los corazones de sus soldados, que le correspondían con una total lealtad (...)". [“(...) Such banquets were enlivened by slaves specializing in music, with their flutes and lutes. With all this, he created an atmosphere of extraordinary diversion and so gained the hearts of his soldiers, who corresponded with total loyalty (...)"]
} 
From these remains, it can be deduced that Ibn Mardanīsh endowed himself with the visual dignity of a powerful sovereign who remained independent against the Almohad domination of the rest of alAndalus. His political persona was complemented by visual propaganda in the form of palace buildings and complexes intended to reflect the magnificence of his reign. For all these reasons, it is likely that for the pictorial decoration of the dome he summoned craftsmen from the Maghreb or in particular from Ifrīqiya, and thus ensured a style of decoration associated to what the Abbasid caliphs had had in Samarra in the third/ninth century. ${ }^{61}$ In addition, it is worth noting that this gesture can be explained as an attempt to regain the Caliphal dignity lost by the Abbasid caliphs themselves in that sixth /twelfth century.

In the case of Norman Sicily, the monarch's attempt to generate a celestial vault befitting his royal dignity has already been shown. The adoption of motifs inspired by the courtly iconography used in Fatimid Egypt and earlier in Abbasid Samarra probably responds to the wishes of the monarch, but also to the personal vocabulary of the craftsmen, most likely coming from Fatimid Egypt. It is even likely, as Gelfer-Jorgensen has shown, that Roger II adopted and assumed elements of Islamic art in order to continue the artistic context of the indigenous population of the island. ${ }^{62}$

In short, and to end my paper, my understanding is that that behind the adoption of Abbasid painting in these Andalusian and Christian manifestations of the sixth/twelfth century lay the desire to reflect unity and power. It is true that the style of these paintings was what was familiar to the craftsmen of Palermo, and probably to those from the Maghreb who worked in Murcia. However, I believe that behind this circumstance there lay a very clear propagandistic intention, and it should not be forgotten that Abbasid painting itself adopted models and types from Sasanian painting. The idea was to recreate those spaces enjoyed by the great Abbasid caliphs, and of course of the powerful Sasanian kings.

\section{ACKNOWLEDGEMENTS}

My special thanks to Pedro Marfil, Professor Professor in the Department of History of Art, Archaeology, and Music in the University of Córdoba (Spain) and to $\mathrm{M}^{\mathrm{a}}$ Ángeles Gómez, Curator of the Archaeological Museum of Murcia for her help and for providing the images of Murcia.

\section{WORKS Cited SECTION}

Adly, Hanaa M. "A Study on Islamic Human Figures Representation in Light of a Dancing Scene", Aga Khan Program for Islamic Architecture (AKPIA/MIT), published in 2007/08 AKPIA@ MIT visiting fellows, Studies in Architecture, History \& Culture

Agnello, Fabrizio. "The Painted Ceiling of the Cappella Palatina in Palermo: an Essay on its Geometric and Constructive Features". Muqarnas: an Annual on the Visual Culture of the Islamic World 27 (2010).

Ahmad, A. A History of Islamic Sicily. Ed. Edinburgh University Press. Edinburgh, 1975.

Al-'Udhrī, Tarș̄̄ al-akhbār wa-tanwī' al-āthār wa-l-bustān fì gharā'ib al-buldān wa-l-masālik ilà jamī' al-mamālik in Fragmentos geográfico-históricos de al-Masālik ilà ŷam̄̄' al-mamālik, edited by 'Abd al-Azīz al-Ahwānī. Madrid: Instituto de Estudios Islámicos, 1965.

Albulafia, David. Italy, Sicily and the Mediterranean 1100-1400. VARIORUM COLLECTED STUDIES SERIES. Aldershot (Great Britain), Burlington (USA): Ashgate. Variorum, 1987.

Almagro Basch, Martín; Caballero Zoreda, Luis; Zozaya Stabel-Hansen, Juan; Almagro, Antonio. Qusayr 'Amra. Residencia y baños omeyas en el desierto de Jordania. Granada: El Legado andalusí, 2002.

Amari, Michele, Cavallari, Saverio, Boglino, Luigi and Carini, Isidoro La Cappella di San Pietro nella Reggia di Palermo, dipinta e cromolitografata da Andrea Terzi (Palermo, 1889: repr. Palermo, 1987).

Amari, Michele. Storia dei musulmani di Sicilia. Firenze: Felice Le Monnier, 1854-1872. V. 2. 1858.

\footnotetext{
${ }^{61}$ On the coins minted by Ibn Mardanīsh can be read a message of Sunni unity addressed to the Abbasid caliph of Baghdad faced with the Almohad threat. See Guichard, L'Espagne et la Sicile, 178.

${ }^{62}$ Gelfer-Jorgensen, Medieval Islamic symbolism, 158.
} 
Arié, Rachel. "Viajeros de Occidente a Oriente.” In Al-Andalus y el Mediterráneo, edited by Ma Jesús Viguera and Concepción Castillo Castillo, 185-193. Granada: Lunwerg, 1995.

Azuar Ruiz, Rafael. "Al-Andalus y el comercio mediterráneo del siglo XI, según la dispersión y distribución de las producciones cerámicas." In Actas I Curso sobre la Península Ibérica: La Península Ibérica y el Mediterráneo entre los siglos XI y XII, edited by Fernando Valdés Fernández and Pedro Luis Huerta Huerta, 51-78. Aguilar de Campoo (Palencia): Fundación Santa María la Real, Centro de Estudios del Románico, 1998.

Baer, Eva. "The Human Figure in Early Islamic Art: Some Preliminary Remarks." Muqarnas: An Annual on Islamic Art and Architecture 16 (1999): 32-41.

Behrens-Abouseif, Doris. 1993. "Muḳarnas.” In Encyclopaedia of Islam. 2nd ed., 501-506. Leiden: Brill (VII).

Bloom, Jonathan. "Almoravid geometric designs in the Pavement of the Cappella Palatina in Palermo." In The iconography of Islamic art: studies in honour of Robert Hillenbrand, edited by Bernard O'Kane. Edinburgh: Edinburgh University Press, 2005.

Bloom, Jonathan. "The Introduction of The Muqarnas into Egypt." Muqarnas: An Annual on Islamic Art and Architecture 5 (1988): 21-28.

Bosch Vilá, Jacinto. “¿Mocárabes en el arte de la taifa de Almería?.” Cuadernos de Historia del Islam 8 (1977): 139-160.

Bosworth, Clifford Edmund. The new islamic dynasties. A chronological and genealogical manual. Edinburgh: Edinburgh University Press, 2004.

Cabañero Subiza, Bernabé, and Herrero Ontañón, Valero. "Nuevos datos para el estudio de la techumbre de la ampliación de Al-Hakam II de la Mezquita aljama de Córdoba. Cuestiones constructivas." Artigrama 16 (2001): 257-283.

Carrillo Calderero, Alicia. "Architectural Exchanges between North Africa and al-Andalus: the introduction of muqarnas." Journal of North African Studies (JNAS), A special issue on Facets of exchange between North Africa and the Iberian Peninsula, Vol. 19, Num. 1 (2014): 68-82.

Carrillo Calderero, Alicia. "La influencia del arte sasánida en la decoración arquitectónica 'abbāssí: de la fragmentación de la trompa de esquina a la creación de un sistema de decoración tridimensional." Boletín de Arte 32/33 (2012): 91-115.

Carrillo Calderero, Alicia. "Compendio de los Muqarnas: Génesis y Evolución (siglos XI-XV).” PhD diss., University of Córdoba, 2007 (published in CD-ROM, edited by Servicio de Publicaciones de la Universidad de Córdoba, in Córdoba, 2009.

Cilento, Adele and Vanoli, Alessandro. Arabi e Normandi in Sicilia en el sud dell'Italia. Udine: MAGNUS, 2008.

Creswell, Keppel Archibald Cameron. The Muslim Architecture of Egypt. Oxford: Clarendon Press, 1952.

Cruikshank Dodd, Erica. "Siculo-Arabic Ivories. Christian motifs in Muslim painting." In Siculoarabic Ivories and Islamic Painting 1100-1300, edited by David Knipp. München: Hirmer, 2011.

Curčić, Slobodan, "Further thoughts on the palatine aspects of the Cappella Palatina in Palermo." In The Cappella Palatina in Palermo. History, Art, Functions, edited by Würth Foundation by Thomas Dittelbach [German/Italian/English]. Künzelsau: Swiridoff-Verlag, 2011.

Dahmani, Fatma. "Remarques sur quelques fragments de peinture murale trouvés à Murcie." Tudmīr 1 (2009): 163-175.

De Beylié, Léon. La Kalaa des Beni-Hammad. Paris: E. Levoux, 1909.

Delgado Valero, Clara. "El arte de Ifrīqiya y sus relaciones con distintos ámbitos del mediterráneo: alAndalus, Egipto y Sicilia." Al-Qanțara 17 (1996): 291-311.

Dokmak, Ahmed Mahmoud. 2004. "Estudio de los elementos islámicos en la arquitectura mudéjar en España a través de las bóvedas mocárabes y de ejemplos de la epigrafía árabe." Unpublished thesis (PhD), Universidad Complutense, Madrid.

Ecochard, Michel. Filiation de monuments grecs, byzantins et islamiques. Paris: Geuthner, 1977.

Ettinghausen, Richard, and Grabar, Oleg. Arte y Arquitectura del Islam. 650-1250. Madrid: Cátedra, 2000. [1st ed. 1987. The Art And Architecture of Islam 650-1250. London: Penguin Books.] 
García Avilés, A. "Arte y poder en Murcia en la época de Ibn Mardanîsh (1147-1172)." In El Mediterráneo y el arte español: Actas del XI Congreso del CEHA, Valencia septiembre 1996, edited by Joaquín Bérchez and Amadeo Serra Desfilis, 31-37. Valencia: Comité español de Historia del Arte, 1998.

García García, Francisco de Asís. "El soberano en al-Andalus." Revista digital de iconografía medieval, vol. II, $\mathrm{n}^{\circ} 4$ (2010): 61-71.

Garofalo, Vincenza. "A Methodology for Studying Muqarnas: The Extant Examples in Palermo." Muqarnas: An Annual on Islamic Art and Architecture 27 (2010): 357-406.

Gelfer-Jorgensen, Mirjam. Medieval Islamic symbolism and the paintings in the Cefalu Cathedral. Leiden: E.J. Brill, 1986.

Gómez-Moreno, El arte árabe español hasta los Almohades; Arte mozárabe. Madrid: Plus-Ultra, 1951.

Guichard, Pierre. L'Espagne et la Sicile musulmanes aux XIe et XIIe siecles. Lyon: Presses universitaires de Lyon, 1991.

Grabar, Oleg. La formación del arte islámico. Madrid: Cátedra, 1986. [1st ed. 1973. The Formation of Islamic Art. New Haven: Yale University Press].

Grube, Ernst J. and Johns, Jeremy. The Painted Ceiling of the Cappella Palatina [Islamic Art, Supplement I], The Bruschettini Foundation for Islamic and Asian Art and The East-West Foundation: Genova and New York, 2005.

Heinrichs, Wolfhart. "The Etymology of Muqarnas: Some Observations." In Humanism, Culture, and Language in the Near East: Studies in Honor of Georg Krotkoff, edited by Asma Afsaruddin and A. H. Mathias Zahniser, 175-184. Winona Lake, Ind: Eisenbrauns, 1997.

Hernández Jiménez, Félix. "La techumbre de la Gran Mezquita de Córdoba.” Archivo Español de Arte y Arqueología 4 (1928): 191-225.

Herzfeld, Die Malereien von Samarra. Berlin: Dietrich Reimer / Ernst Vohsen, 1927.

Hoffman, Eva R. "Pathways of Portability: Islamic and Christian interchange from the tenth to the twelfth century." Art History 24, no 1 (2001): 17-50.

Hoffman, Eva R. "Between East and West: the Wall Paintings of Samarra and the Construction of Abbasid Princely Culture." Muqarnas: an Annual on the Visual Culture of the Islamic World. Frontiers of Islamic Art and Architecture: Essays in Celebration of Oleg Grabar's Eightieth Birthday. Special volume. (2008): 107-132.

Hunt, Lucy-Anne. "Ceiling and Casket at the Cappella Palatina and Christian Arab Art between Sicily and Egypt in the Twelfth and Thirteenth Centuries." In Siculo-arabic Ivories and Islamic Painting 1100-1300, edited by David Knipp, 169-197. München: Hirmer, 2011.

Johns, Jeremy. Arabic Administration in Norman Sicily. The Royal Dīwān. Cambridge: Cambridge, University Press, 2002.

Johns, Jeremy. "I Re normanni e i Califfi fățimiti. Nuove prospettive su vecchi materiali." In Del nuevo sulla Sicilia musulmana. Atti della Giornata di studio. Roma, 3 maggio 1993, edited by B. Scarcia Amoretti, 1-50. Roma: Academia nazionale dei Lincei. Fondazione Leone Caetani, 1995.

Lézine, Architecture de L'Ifriqiya. Recherches sur les monuments aghlabides. Archéologie Méditerranéenne vol. II. France: C. Klincksieck, 1996.

Lirola Delgado, Jorge. El poder naval de al-Andalus en la época del Califato Omeya. Granada: Universidad de Granada, Instituto de Estudios almerienses, 1993.

López Monteagudo, Guadalupe. "Platería sasánida y mosaicos romanos." In Persia y España en el diálogo de las civilizaciones. Historia, religión, cultura, edited by José $\mathrm{M}^{\mathrm{a}}$ Blázquez, 155-172. Madrid: Ediciones Clásicas, 2002.

Mallette, Karla. The Kingdom of Sicily, 1100-1250. A Literary History. Philadelphia: University of Pennsylvania Press, 2005.

Mathews, Karen R. "Plunder of war or objects of trade? The reuse and reception of Andalusi objects in medieval Pisa." Journal of Medieval Iberian Studies 4:2 (2012): 233-258.

Metcalfe, Alex. The Muslims of Medieval Italy. Edinburgh: Edinburgh University Press, 2009. 
Metcalfe, Alex. Muslims and Christians in Norman Sicily. Arabic speakers and the end of Islam. London, New York: Routledge Curzon, 2003.

Molina López, Emilio. 1972. "La kūra de Ṭudmīr según al-`Uḍ̂̄ (s. XI)." Cuadernos de Historia del Islam 4: 7-113.

Molinari, Alessandra. "La Sicilia islámica. Riflessioni sul passato e sul futuro della ricerca in campo archeologico." In La Sicile à l'époque islamique: questions de méthode et renouvellement récent des problématiques. Actes de la table ronde de Roma, 25 et 26 octobre 2002, edited by Alessandra Molinari and Annliese Nef, 19-46. Rome: Ecole Française de Rome, 2004.

Momplet Míguez, Antonio Eloy. El arte hispanomusulmán. Madrid: Encuentro, 2004.

Monneret de Villard, Ugo. Le pitture musulmane al soffitto della capella palatina in Palermo. Roma: La librería dello stato, 1950.

Navarro Palazón y Jiménez Castillo y "La arquitectura de Ibn Mardanîsh: Revisión y nuevas aportaciones." In La Aljafería y el Arte del Islam Occidental en el siglo XI, Actas del Seminario Internacional celebrado en Zaragoza los días 1, 2 y 3 de diciembre de 2004, edited by Borrás Gualis, G. M.; Cabañero Subiza, B., 291-350. Zaragoza: Institución Fernando el Católico, 2012.

Navarro Palazón, Julio. "La Dār al-Șugrā de Murcia. Un palacio andalusí del siglo XII." In Colloque International D'Archéologie Islamique. Textes arabes et études islamiques. Le Caire 3-7 février 1993, edited by R.P. Gayrand, 97-123. Cairo: IFAO, 1998.

Navarro Palazón, Julio y Jiménez Castillo, Pedro. In Sharq al-Andalus: resistencia frente a los Almohades. Exhibition 22 December 1993 - 31 January 1994. Centro de Arte Palacio Almudí. Exhibition commissioner, Julio Navarro Palazón. Coordinators: Pedro Jiménez Castillo and Indalecio Pozo Martínez. Murcia: Ayuntamiento de Murcia. Murcia, 1993.

Nicole, David. 1983. "The Cappella Palatina ceiling and the Muslim Military Inheritance of Norman Sicily.” Gladius XVI: 45-145.

Pavón, Basilio. 1968. "Las analogías entre el arte califal de Córdoba y la mezquita mayor de Kairuán en el siglo XI." Cuadernos de la Alhambra 4: 21-38.

Pavón Maldonado, El arte hispanomusulmán en su decoración geométrica. Madrid: Ministerio de Asuntos Exteriores, 1975.

Pavón Maldonado, Tratado de arquitectura hispanomusulmana IV, Mezquitas. Madrid: Consejo Superior de Investigaciones científicas, 2009.

Pérez Higuera, Teresa. Objetos e imágenes de al-Andalus. Barcelona: Lunwerg editores, 1994.

Rice, David Talbot. Islamic painting: a survey. Edinburgh: Edinburgh University Press, 1971.

Rosser-Owen, Mariam. "Mediterraneanism: how to incorporate Islamic art into an emerging field." Journal of Art Historiography 6 (2012): 1-33.

Sālim, 'Abd al-Azīz, 1995. "De al-Andalus a Egipto y de Egipto a al-Andalus." In Al-Andalus y el Mediterráneo, edited by $\mathrm{M}^{\mathrm{a}}$ Jesús Viguera and Concepción Castillo Castillo, 141-147. Granada: Lunwerg.

Seco de Lucena, Luis. "Los palacios del taifa almeriense al-Mu tașim." Cuadernos de la Alhambra 3 (1965): 15-20.

Tabbaa, Yasser. "The Muqarnas Dome: its Origin and Meaning." Muqarnas: An Annual on Islamic Art and Architecture 3 (1985): 61-74.

Torres Balbás, Leopoldo. "Intercambios artísticos entre Egipto y el Occidente musulmán”. Crónica arqueológica de la España musulmana III, Al-Andalus 3 (2) (1935): 411-424.

Torres Balbás, Leopoldo. “Aportaciones del arte de Ifrīqiya al musulmán español de los siglos X y XI”. Crónica arqueológica de la España musulmana III Al-Andalus 3 (2) (1935): 393-396.

Torres Balbás, Leopoldo. Arte almohade, arte nazarí, arte mudéjar. Ars Hispaniae 4. Madrid: Plus Ultra, 1949. 


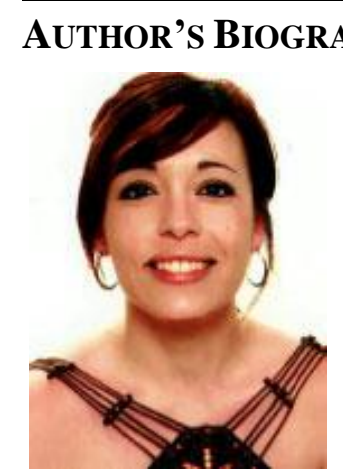

Alicia Carrillo, Phd in History of Art for the University of Córdoba (Spain).Professor in the Department of History of Art, Archaeology, and Music in the University of Córdoba (Spain). Researching Career: I would like to point out that most of my researches and publicationsare dedicated to the study of "muqarnas". This investigation comes from my Doctoral Thesis, called "Compendio de los muqarnas: génesis y evolución (siglos XI-XV)", which was highly marked with summa cum laude by all the members of the board, and was published by the University of Córdoba in 2009. One of its contributions is the uniqueness of a perfect control of the Islamic Art (Muqarnas) and the diffusion of a part of the research, through the publication of some scientific articles in prestigious magazines, such as: Carrillo, Alicia, "The Sasanian Tradition In Abbasid Art: Squinch Fragmentation As The Structural Origin Of The Muqarnas", in Mirabilia Journal 22/2016-1, 2016; Carrillo, Alicia, "Architectural Exchanges between North Africa and the Iberian Peninsula: Muqarnas in al-Andalus", in The Journal of North African Studies. A Special Issue on Facets of Exchange between North Africa and the Iberian Peninsula, vol. 19, No 1, 2014; Carrillo, Alicia, "La influencia del arte sasánida en la decoración arquitectónica 'abbāssí: de la fragmentación de la trompa de esquina a la creación de un sistema de decoración tridimensional", in Boletín de Arte, Departamento de Historia del Arte, Universidad de Málaga, 2012 or Carrillo, Alicia, "Decoración tridimensional en al-Andalus: introducción y uso de los mocárabes", Boletín Museo e Instituto Camón Aznar, № 104, Obra Social de Ibercaja, ESPAÑA, 2009. Likewise, Papers and Lectures such as Carrillo, Alicia, "Muqarnas domes: an interpretation of the Heavenly Vault", at International Congress "Domes in the World", Dipartimento di Architettura, Disegno, Storia e Progetto. Università degli Studi di Firenze, Fondazione Romualdo del Bianco, Collegio degli Ingegneri della Toscana, March 2012, Florence (Italy), among other publications. 